\title{
Lubricants having zinc borate by homogeneous precipitation and Span 60 in spindle oil
}

\author{
Sevdiye Atakul Savrik', Burcu Alp², Mehmet Gönen ${ }^{3}$, Devrim Balkose ${ }^{4, *}$ \\ ${ }^{1}$ Akzo Nobel, Izmir, 35410 Turkey, \\ ORCID orcid.org/0000-0002-1402-0569 \\ ${ }^{2}$ Süleyman Demirel University, Department of Chemical Engineering, Isparta, 32260, Turkey \\ ORCID orcid.org/0000-0002-0380-2020 \\ ${ }^{3}$ Süleyman Demirel University, Department of Chemical Engineering, Isparta, 32260, Turkey \\ ORCID orcid.org/0000-0001-5780-4622 \\ ${ }^{4}$ Izmir Institute of Technology, Department of Chemical Engineering, Izmir, 35430, Turkey \\ ORCID orcid.org/0000-0002-1117-9486
}

\section{ARTICLE INFO}

Article history:

Received June 12, 2021

Accepted August 11, 2021

Available online September 30, 2021

Research Article

DOI: 10.30728/boron.951463

Keywords:

Four ball tests

Homogeneous precipitation

Lubricants

Span 60

Zinc borate

\begin{abstract}
Nano particles of zinc borate were obtained by homogeneous precipitation method which is based on dissolving zinc borate in ammonia and precipitating it as nano particles by slow evaporation of ammonia. The synthesized zinc borates were characterized by advanced analytical techniques. Zinc borate nano particles were used as a lubricant additive to spindle oil having Span 60 dispersant. The particles were well dispersed in spindle oil as shown by optical microscopy of the oils. Four ball tests of the lubricants indicated zinc borate lowered $(61.8 \%)$ the wear scar diameter significantly. The hardness of wear surfaces of test balls was reduced from $688 \mathrm{HV}$ to $618 \mathrm{HV}$ and presence of zinc borate particles embedded on the surface indicated a flexible skin was formed. Therefore the pressure was decreased due to increase of the contact area of the balls. The surface roughness was also decreased from $35.63 \mathrm{~nm}$ to $27.60 \mathrm{~nm}$ by the addition of zinc borate to spindle oil having Span 60 . Zinc borate prepared by homogeneous precipitation technique lowered the wear of the surfaces that rub to each other.
\end{abstract}

\section{Introduction}

Nano particles of zinc borate hydrates can be obtained using different methods. $4 \mathrm{ZnO} \cdot \mathrm{B}_{2} \mathrm{O}_{3} \cdot \mathrm{H}_{2} \mathrm{O}$ nanoparticles can be synthesized by dissolving the precipitate obtained from borax decahydrate and zinc nitrate solution [1] or by dissolving $2 \mathrm{ZnO} \cdot 3 \mathrm{~B}_{2} \mathrm{O}_{3} \cdot 3.0-3.5 \mathrm{H}_{2} \mathrm{O}$ [2] in ammonia and then reprecipitating it with the help of evaporation of ammonia by heating the solution. Forming zinc borate nano particles in mineral oil allows the use of the mixture as lubricating oil [3]. Hydrophobic zinc borate nanoparticles could be obtained from zinc oxide, boric acid and oleic acid in water [4]. Saffari et al. prepared nano-sized zinc borates at $200^{\circ} \mathrm{C}$ and 15 bar pressure from aqueous borax and zinc nitrate solutions [5]. The surfactants are added to the mixture in order to obtain nano zinc borate particles with different geometries [6-9]. Agglomerates of nano zinc borate platelets were obtained from nano zinc oxide and boric acid at $85^{\circ} \mathrm{C}$ with surfactants or without surfactants. Either $2 \mathrm{ZnO} \cdot 3 \mathrm{~B}_{2} \mathrm{O}_{3} \cdot 7 \mathrm{H}_{2} \mathrm{O}, 2 \mathrm{ZnO} \cdot 3 \mathrm{~B}_{2} \mathrm{O}_{3} \cdot 3.5 \mathrm{H}_{2} \mathrm{O}$ or $3 \mathrm{ZnO} \cdot 3 \mathrm{~B}_{2} \mathrm{O}_{3} \cdot 5 \mathrm{H}_{2} \mathrm{O}$ were obtained by mixing aqueous borax and sodium nitrate solutions in different proportions by controlling the temperature $\left(80^{\circ} \mathrm{C}-90^{\circ} \mathrm{C}\right)$ and $\mathrm{pH}$ [10]. The effects of temperature $\left(45^{\circ} \mathrm{C}-85^{\circ} \mathrm{C}\right)$, mix- ing rate $(400-500 \mathrm{rpm})$ and reactant feed rate $(300-$ $900 \mathrm{~cm}^{3} \mathrm{hr}^{-1}$ ) on zinc borate particle size were investigated by Polat and Sayan [11]. Zinc sulfate hydroxide $\left(\mathrm{Zn}_{4} \mathrm{SO}_{4}(\mathrm{OH})_{6}\right)$ and boric acid in aqueous solution were used in zinc borate preparation [12]. The morphology of zinc borates $\left(2 \mathrm{ZnO} \cdot 3 \mathrm{~B}_{2} \mathrm{O}_{3} \cdot 3 \mathrm{H}_{2} \mathrm{O}\right)$ changed from platelet to polyhedron at the reaction temperature of $90^{\circ} \mathrm{C}$ with increasing the water content in the reaction solution [12].

Zinc borates had flame retarding effect in epoxy resin [1], polyvinyl chloride [2], polyethylene [4], polyurethane [10], polyvinyl alcohol [12] and cellulose [13]. Cotton fabric that was dried after immersing in a suspension of nano particles of zinc borate had flame retardant properties [13].

Many studies were made using zinc borate nanoparticles as lubricant additives [3]. Zinc borate nanoparticles by inverse emulsion method in mineral oil using Span 60 lowered friction coefficient and wear scar diameter in four ball tests compared to that of pristine mineral oil [3]. Nano zinc borate with $40 \mathrm{~nm}$ size dispersed in mineral oil lowered the wear scar diameter by $50 \%$ and friction coefficient by $20 \%$ [14]. Nano zinc 
borates with $600 \mathrm{~nm}$ size improved the tribological properties of water-based drilling fluids [5]. Sunflower oil containing zinc borate with a particle size of 500 $800 \mathrm{~nm}$ lowered the friction and wear, as well [15]. The tribological capacity of zinc borate ultrafine powders modified with hexadecyltrimethoxysilane or oleic acid in mineral oil can be explained by the formation of continuous tribo-film on the worn surface which improves the friction and wear properties [16].

The present study aims the synthesis of zinc borate nano particles which are used as a lubricant additive in order to reduce the wear of the metal machine parts that rub to each other. For this purpose, the aqueous zinc nitrate and borax solutions were mixed and the precipitate was dissolved with ammonia. Nano particles of zinc borate were formed as the ammonia was evaporated by heating. The nano particles were characterized by advanced analytical methods. The effect of nano zinc borate on tribological behavior of spindle oil was investigated. Both the state of dispersion of particles in lubricants and tribological behavior of the lubricants were determined and the worn test surfaces were characterized by elemental analysis, atomic force microscopy (AFM), scanning electron microscopy (SEM) and Vickers hardness.

\section{Materials and Methods}

Borax decahydrate (99.9\%, Eti Maden Inc.), zinc nitrate hexahydrate $(99.9 \%$, Fluka), Sorbitan monostearate (Span 60) from Sigma Aldrich, ethanol (99.8\%) from Riedel were used in the experiments. Light neutral oil called as spindle oil (SN 150) (TÜPRAŞ A.Ş) was used as a base oil for lubricant preparation.

\subsection{Synthesis of Zinc Borate}

The precipitation of zinc borate in the bulk phase was carried out by homogeneous precipitation method $[2,6,17] .20 \mathrm{~cm}^{3} 1.25 \mathrm{~mol} \mathrm{dm}{ }^{-3}$ zinc nitrate and $30 \mathrm{~cm}^{3}$ $0.08 \mathrm{~mol} \mathrm{dm}^{-3}$ borax solution were mixed at $45^{\circ} \mathrm{C}$. The formed white precipitate was dissolved by addition of $12.5 \mathrm{~cm}^{3} 25 \%$ ammonia. The mixture was added to 75 $\mathrm{cm}^{3}$ water and mixed at $600 \mathrm{rpm}$ by magnetic stirring at $45^{\circ} \mathrm{C}$ in an $8 \mathrm{~cm}$ diameter open container. During the mixing the $\mathrm{pH}$ of the solution was monitored by a $\mathrm{pH}$ meter. Nano zinc borate precipitated while ammonia was slowly evaporated. The experiments were repeated for different heating periods of 3, 5, 6,12 and 15 hours in order to reveal the effect of heating time on the tribological properties of the lubricants The volume of each solution was measured at the end of the heating period. The white sediment for each heating period was separated by centrifuging at $9000 \mathrm{rpm}$ for 10 minutes, washed with ethanol and water and recentrifuged. The sediments were dried at $40^{\circ} \mathrm{C}$ under vacuum for 12 hours. A lower drying temperature $\left(40^{\circ} \mathrm{C}\right)$ was applied rather than that of the previous investigators $[2,17]$ drying temperature $\left(70^{\circ} \mathrm{C}\right)$ to avoid further reaction and growth of particles during drying.

\subsection{Characterization of Zinc Borate}

The Fourier Transform Infrared (FTIR) spectra of the samples were attained by $\mathrm{KBr}$ transmission method in Shimadzu FTIR 8601. For thermal characterization, the samples $(10-15 \mathrm{mg})$ were heated from room temperature to $600^{\circ} \mathrm{C}$ at $10^{\circ} \mathrm{C} \mathrm{m^{-1 }}$ under $\mathrm{N}_{2}$ flow of 40 $\mathrm{cm}^{3} \mathrm{~min}^{-1}$ in alumina sample holder in Thermogravimetric (TG) analysis and in aluminum pan for Differential Scanning Calorimetric (DSC) analysis in Shimadzu TGA 51 and Shimadzu DSC 50, respectively. X ray diffraction diagrams (XRD) of the samples were obtained with $\mathrm{CuK}_{\alpha}$ radiation with $0.154 \mathrm{~nm}$ wavelength in Philips Xpert-Pro. SEM micrographs of gold sputtered samples fixed to a double sided tape were achieved using Philips XL30 SFEG. C, H, N, S content of the samples were determined in CHNS analyzer (Leco). The experiments run in dublicate and the average results were reported. The particle size distribution of samples dispersed in water using $1 \%$ calgon was measured by Malvern Mastersizer 2000. An analytical titration method described by Savrik [14] was used for determination of $B$ and $\mathrm{Zn}$ contents of the samples. The titration experiments were run in triplicate and their average was reported.

\subsection{Preparation of Lubricants}

The lubricants were prepared using sorbitan monostearate as a surfactant. Firstly, $1 \mathrm{~g}$ sorbitan monostearate was dissolved in $100 \mathrm{~cm}^{3}$ spindle oil and heated up to $70^{\circ} \mathrm{C}$, secondly, $1 \mathrm{~g}$ zinc borate prepared at different heating periods during its preparation was dispersed in the spindle oil. The lubricants are coded as L1: spindle oil, L2: spindle oil with surfactant, L3: spindle oil with surfactant and zinc borate heated for 6 hours, L4: spindle oil with surfactant and zinc borate heated for 12 hours and L5: spindle oil with surfactant and zinc borate heated for 15 hours. The lubricants were mixed at $150^{\circ} \mathrm{C}$ at $20000 \mathrm{rpm}$ for 2 minutes using a 700 Watt homogenizer (OMNI GLH) with $10 \mathrm{~mm}$ diameter rotor-stator generator prob. The samples were further stirred for 2 hours using a magnetic stirrer (Yellowline MSH Basic) at $600 \mathrm{rpm}$.

\subsection{Characterization of Lubricants}

The microphotographs of lubricants at room temperature were taken with an optical microscope (Olympus BX60M) fitted with a digital camera (Olympus DP25). The avarege diameters of particles in oil were measured by Olympus DP2-BSW program.

A four-ball wear test machine (Falex Corp.) was used for measurement of the friction coefficient and wear scar diameter of test balls for the lubricants L1-L5. The test was performed according to ASTM D 4172-94. 


\subsection{Characterization of Balls After Four Ball Tests}

\subsubsection{Cutting of fixed balls}

Fixed balls used for four ball tests for spindle oil (L1), spindle oil with dispersant (L2) and spindle oil with dispersant and zinc borate heated for 15 hours (L5) during its preparation were cut into half with a microcutter (Metkon Microcut Precision Cutter) operating at 2000 rpm using water as coolant. Thus worn surfaces of the balls could further be examined by SEM, EDX, AFM and microhardness testing.

\subsubsection{Microhardness tests}

Microhardness of the unworn and worn surfaces of the fixed balls was measured with digital microhardness tester (TIME HVS-1000) operating at $4.9 \mathrm{~N}$ load and $20 \mathrm{~s}$ indentation time. Average of the measurements at three points was reported as the hardness of the ball surface in Vicker's Hardness (VH).

\subsubsection{Atomic force microscopy}

Multimode Atomic Force Microscope (Digital Instrument, Nanoscope IV) was used for measurement of roughness of the wear scars of the fixed balls.

\subsection{4. $E D X$}

EDX analysis of the uncoated samples was achieved using Philips XL30 SFEG.

\section{Results and Discussion}

\subsection{Synthesis of Zinc Borate}

Nano-sized zinc borate particles were produced according to homogeneous precipitation technique described by Mergen et al [2], Ipek [6] and Ting et al. [17]. The mechanism of this method is explained as the following. Firstly, zinc nitrate to $\mathrm{Zn}^{2+}$ cations and $\mathrm{NO}_{3}{ }^{-}$anions and borax decahydrate dissociates to $\left[\mathrm{B}_{4} \mathrm{O}_{5}(\mathrm{OH})_{4}\right]^{2-}$ and $\mathrm{Na}^{+}$cation in the solutions. When these two solutions are mixed $\mathrm{Zn}\left[\mathrm{B}_{4} \mathrm{O}_{5}(\mathrm{OH})_{4}\right]$ precipitates. The precipitate dissolves forming $\mathrm{Zn}\left(\mathrm{NH}_{3}\right)_{4}{ }^{2+}$ complex as ammonia is added to the mixture. As the solution was heated at $45^{\circ} \mathrm{C}$, ammonia and water are evaporated from the system. 17, 36, 93 and $116 \mathrm{~cm}^{3}$ water was eliminated from total volume of $137.5 \mathrm{~cm}^{3}$ solution for 3, 5, 6 and 15 hours of heating. The solution become concentrated at long periods of heating and by products such as sodium nitrate precipitates besides zinc borates. The by products were eliminated by washing the precipitates. The $\mathrm{pH}$ value of the ammonia added solution was 10 initially and it was lowered with time as it was heated at $45^{\circ} \mathrm{C}$ in the open container. At the end of $3,6,12$ and 15 hours, $\mathrm{pH}$ values were measured as $8.8,8.2,6.6$ and 5.3 , respectively. The decrease in $\mathrm{pH}$ was due to the removal of ammonia by heating and reaction 1 as reported by Savrik [18].
$\mathrm{Zn}\left[\mathrm{B}_{4} \mathrm{O}_{5}(\mathrm{OH})_{4}\right] \cdot \mathrm{H}_{2} \mathrm{O}(\mathrm{s})+2 \mathrm{H}_{2} \mathrm{O}(\mathrm{l}) \rightarrow$

$$
\mathrm{Zn}\left[\mathrm{B}_{3} \mathrm{O}_{3}(\mathrm{OH})_{5}\right] \mathrm{H}_{2} \mathrm{O}(\mathrm{s})+\mathrm{B}(\mathrm{OH})_{3}(\mathrm{~s}) \text { (1) }
$$

$\mathrm{Zn}\left[\mathrm{B}_{4} \mathrm{O}_{5}(\mathrm{OH})_{4}\right] \cdot \mathrm{H}_{2} \mathrm{O}$ precipitates when the zinc ion concentration satisfies its solubility parameter. The precipitation reaction of zinc cations and borate can only reach to molecular level due to small concentration of zinc ions. The growth of the crystals was inhibited owing to the presence of few $\mathrm{Zn}^{2+}$ ions in the solution. Thus nano-sized particles form. Further heating the mixture leads to the formation of $\mathrm{Zn}\left[\mathrm{B}_{4} \mathrm{O}_{5}(\mathrm{OH})_{4}\right] \cdot \mathrm{H}_{2} \mathrm{O}$ and then $\mathrm{Zn}\left[\mathrm{B}_{3} \mathrm{O}_{3}(\mathrm{OH})_{5}\right.$. However at higher $\mathrm{pH}$ values $(10-12) \mathrm{Zn}^{2+}$ ions reacts with $\mathrm{OH}^{-}$and $\mathrm{NO}^{3-}$ ions to form zinc hydroxyl nitrate, $\mathrm{Zn}_{5}(\mathrm{OH})_{8}\left(\mathrm{NO}_{3}\right)_{2} \cdot 2 \mathrm{H}_{2} \mathrm{O}$ as indicated by Savrik et al [14].

\subsection{Characterization of Zinc Borates}

The FTIR spectra of zinc borates prepared are shown in Figure 1a They exhibit the specific peaks of borate groups reported in the literature $[17,19]$. The band at $3300 \mathrm{~cm}^{-1}$ is due to hydrogen bonded $\mathrm{O}-\mathrm{H}$ groups stretching vibration. The band at $1634 \mathrm{~cm}^{-1}$ belonged to $\mathrm{H}-\mathrm{O}-\mathrm{H}$ bending vibration indicating that the samples had crystal water. The stretching bands of $\mathrm{B}(3)-\mathrm{O}$ and $\mathrm{B}(4)-\mathrm{O}$ are observed at 1343 and $1050 \mathrm{~cm}^{-1}$ respectively. The peaks between $745-658 \mathrm{~cm}^{-1}$ belong to outof-plane bending mode of $\mathrm{B}(3)-\mathrm{O}$. The peak intensities also do not increase with mixing time.

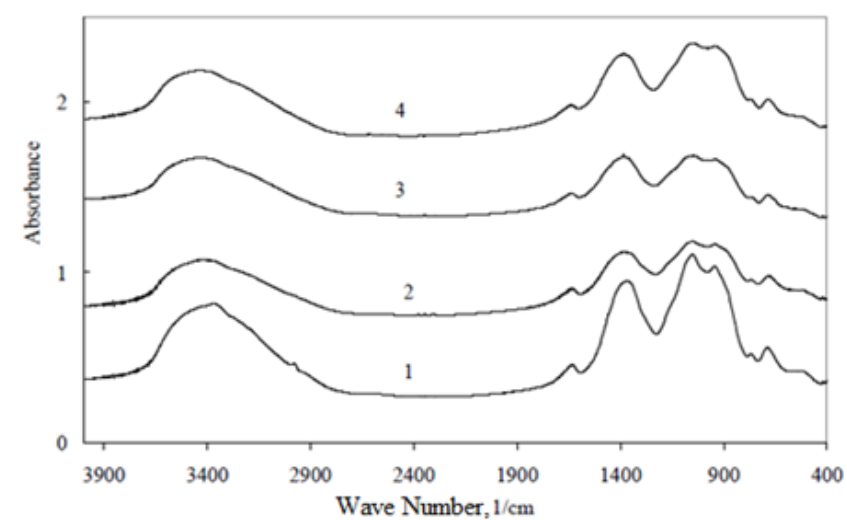

Figure 1. FTIR spectra of the samples obtained by heating 3 (Plot 1), 6 (Plot 2), 12 (Plot 3 ) and 15 (Plot 4 ) hours at $45^{\circ} \mathrm{C}$ during their preparation.

XRD diagrams of the zinc borates in Figure 2 have no sharp diffraction peaks. The line broadening due to nano-sized crystals formed and overlap of the broadened peaks results in a diffraction diagram similar to that of an amorphous substance. The precipitates obtained from dilute zinc nitrate and borax solutions at $25^{\circ} \mathrm{C}$ by Savrik et al [14] had similar $\mathrm{x}$-ray diffraction diagrams of the samples obtained in the present study. On the other hand İpek [6] obtained sharp peaks at $2 \theta$ values of $13.2^{\circ}, 17.5^{\circ}, 19.8^{\circ}, 21.2^{\circ}, 23.4^{\circ}, 26.5^{\circ}, 28.5^{\circ}, 30.9^{\circ}$, $33.4^{\circ}, 35.3^{\circ}, 37.4^{\circ}, 40.2^{\circ}, 41.1^{\circ}, 43.3^{\circ}, 44^{\circ}, 47.2^{\circ}$, $50.3^{\circ}$, and $54.9^{\circ}$ belonging to $2 \mathrm{ZnO} \cdot 3 \mathrm{~B}_{2} \mathrm{O}^{\circ} \cdot 7 \mathrm{H}_{2} \mathrm{O}$ (JCPDS 75-0766) for the nano particles with $211 \mathrm{~nm}$ mean size. The primary particle size of particles in the 
present study should have been much smaller since they had very large line broadening. According to Scherrer Equation.

$$
\mathrm{L}=\mathrm{k} \lambda /(\mathrm{B} \cos \theta)
$$

Where $L$ is the size of the crystals perpendicular to diffraction plane with $\theta$ angle in $\mathrm{nm}, \mathrm{k}=$ constant which is taken as $0.9, \lambda$ is the wavelength of the $x$-rays. For CuK $_{\alpha}$ radiation the wavelength is $0.1546 \mathrm{~nm}$. $B$ is the breadth of the diffraction line at half height at angle $\theta$. For instance the breadths of the first two peaks at $2 \theta$ values of $13.2^{\circ}$ and $17.7^{\circ}$ of XRD diagram of $2 \mathrm{ZnO} .3 \mathrm{~B}_{2} \mathrm{O}_{3} \cdot 7 \mathrm{H}_{2} \mathrm{O}$ were found as $3.20^{\circ}$ and $3.22^{\circ}$ respectively for particle size of $5 \mathrm{~nm}$ using Scherer equation. The breadth increases to $4.02^{\circ}$ and $4.04^{\circ}$ as the particle size is reduced to $4 \mathrm{~nm}$. This value is sufficient for the overlap of the first two peaks of the XRD diagram of $2 \mathrm{ZnO} .3 \mathrm{~B}_{2} \mathrm{O}_{3} \cdot 7 \mathrm{H}_{2} \mathrm{O}$ at $2 \theta$ value of $13.2^{\circ}$ and $17.7^{\circ}$. The line broadening values of the $\mathrm{x}$-ray peaks increases to $3.6^{\circ}$ and $4.5^{\circ}$ for $2 \theta$ value of $54.9^{\circ}$ for 5 and $4 \mathrm{~nm}$ particle sizes respectively. Thus for 4 to $5 \mathrm{~nm}$ particle size all the x-ray diffraction peaks of $2 \mathrm{ZnO} .3 \mathrm{~B}_{2} \mathrm{O}_{3} \cdot 7 \mathrm{H}_{2} \mathrm{O}$ will be broadened and overlap with each other.

Ting et al. [17] indicated formation of crystalline phases with increased heating period. The diffraction diagrams obtained did not belong to any of the known zinc borates [17].

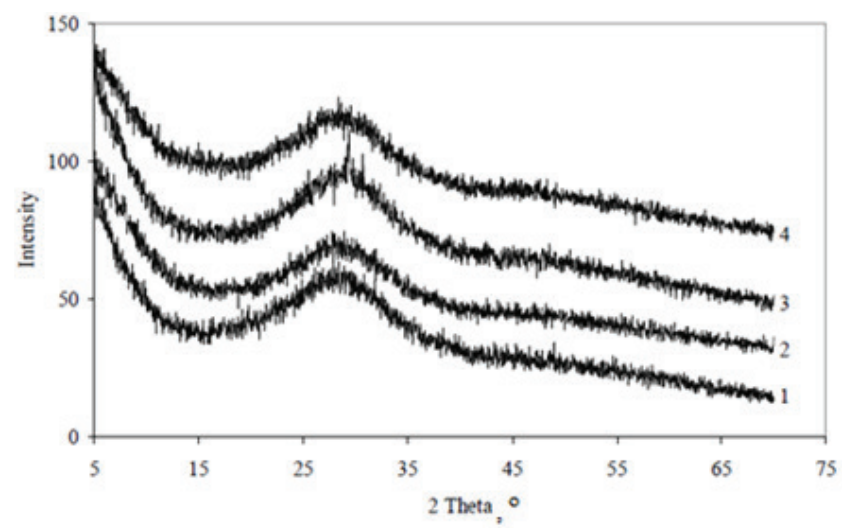

Figure 2. XRD diagrams of samples heated for 3 (Plot 1), 6 (Plot 2), 12 (Plot 3 ) and 15 (Plot 4 ) hours at $45^{\circ} \mathrm{C}$ during their preparation.

The TG curves of the samples are shown in Figure 3. Since all the samples were dried at $40^{\circ} \mathrm{C}$ further heating would eventually cause evaporation of remaining water. The onset of mass loss is $50^{\circ} \mathrm{C}$ for all samples. The first step of the mass loss was completed at $270^{\circ} \mathrm{C}$ for the sample heated for 3 hours and there was a small second step at $520^{\circ} \mathrm{C}$. There was a second step of mass loss at $490^{\circ} \mathrm{C}$ for the sample heated for 6 hours. The sample heated for 9 hours completed its mass loss at $550^{\circ} \mathrm{C}$. The sample heated for 15 hours had a second step of mass loss at $250^{\circ} \mathrm{C}$.

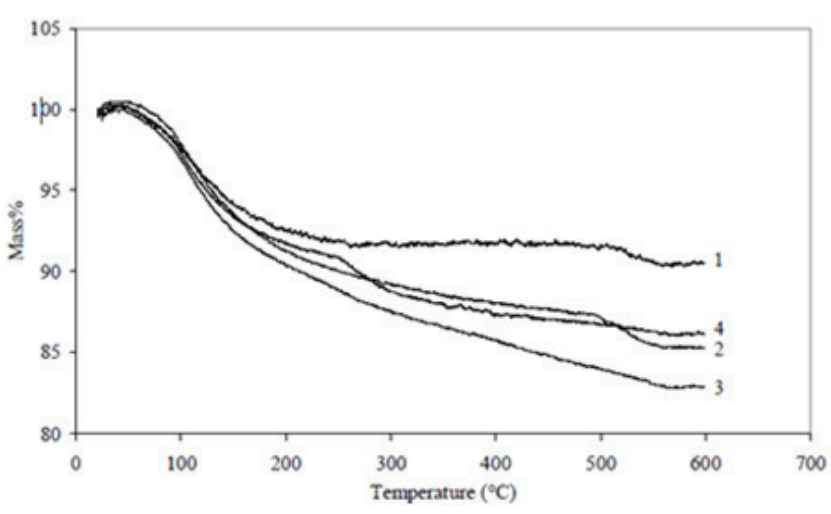

Figure 3. TG curves of samples heated for 3 (Plot 1), 6 (Plot 2), 12 (Plot 3 ) and 15 (Plot 4 ) hours at $45^{\circ} \mathrm{C}$ during their preparation.

Considering dehydration behavior of possible products that will be obtained in the precipitation reaction, their identification was attempted to be made in the present study.

Alp et al. [20] determined the onset of dehydration of zinc borate $2 \mathrm{ZnO} \cdot 3 \mathrm{~B}_{2} \mathrm{O}_{3} \cdot 7 \mathrm{H}_{2} \mathrm{O}, 2 \mathrm{ZnO} \cdot 3 \mathrm{~B}_{2} \mathrm{O}_{3} \cdot 3 \mathrm{H}_{2} \mathrm{O}$ as $129^{\circ} \mathrm{C}$ and $320^{\circ} \mathrm{C}$, respectively, at a $10^{\circ} \mathrm{C} \mathrm{m^{-1 }}$ heating rate. Therefore, the present samples could only be zinc borate with seven mols of water.

Formation of $\mathrm{Zn}_{5}(\mathrm{OH})_{8}\left(\mathrm{NO}_{3}\right)_{2} \cdot 2 \mathrm{H}_{2} \mathrm{O}$ was also possible in homogeneous precipitation reaction. The dehydration of $\mathrm{Zn}_{5}(\mathrm{OH})_{8}\left(\mathrm{NO}_{3}\right)_{2} \cdot 2 \mathrm{H}_{2} \mathrm{O}$ occurs in three steps. The first step at $120^{\circ} \mathrm{C}$ is due to crystal water loss, the second step is at $145-160^{\circ} \mathrm{C}$ because of the de-hydroxylation, whereasthe third step between about 160 $230^{\circ} \mathrm{C}$ is owing to decomposition to $\mathrm{ZnO}$ and nitrogenand oxygen-containing compounds [21]. On the other hand, $4 \mathrm{ZnO} \cdot \mathrm{B}_{2} \mathrm{O}_{3} \cdot \mathrm{H}_{2} \mathrm{O}$ was stable up to around $520^{\circ} \mathrm{C}$ and no considerable weight loss was detected up to this temperature. A sharp decrease in weight (4.4 wt \%.) occurred between 520 and $560^{\circ} \mathrm{C}$ [2].

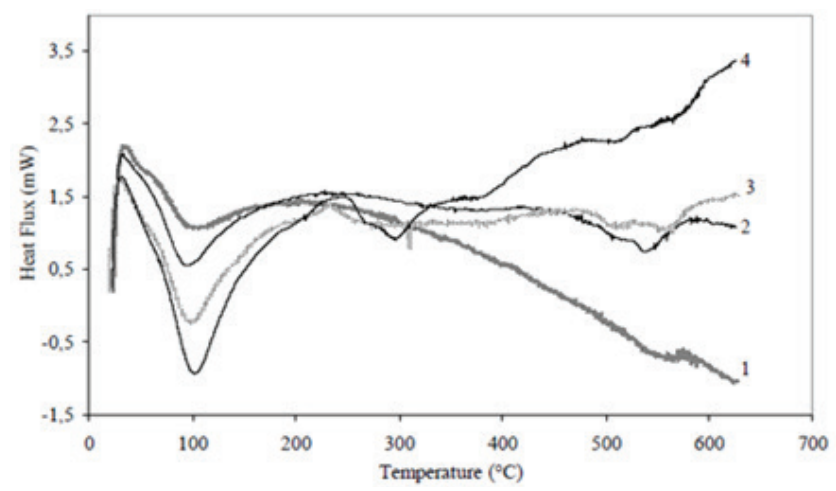

Figure 4. DSC curves of samples heated for 3 (Plot 1), 6 (Plot 2), 12 (Plot 3 ) and 15 (Plot 4 ) hours at $45^{\circ} \mathrm{C}$ during their preparation.

DSC curves of the samples shown in Figure 4 exhibit two endothermic peaks at around $100^{\circ} \mathrm{C}$ and $500^{\circ} \mathrm{C}$ that may be due to loss of free and bound water. Table 1 presents the dehydration behavior of the samples and the first endothermic peak of the samples is re- 
Table 1. Dehydration temperatures and enthalpies of samples prepared by heating for different periods.

\begin{tabular}{ccccccccc}
\hline $\begin{array}{c}\text { Heating } \\
\text { Time }\end{array}$ & $\begin{array}{c}\text { Onset } \\
\left({ }^{\circ} \mathbf{C}\right)\end{array}$ & $\begin{array}{c}\text { Maximum } \\
\left({ }^{\circ} \mathbf{C}\right)\end{array}$ & $\begin{array}{c}\text { Endset } \\
\left({ }^{\circ} \mathbf{C}\right)\end{array}$ & $\begin{array}{c}\mathbf{\Delta H} \\
\left(\mathbf{J ~ g ~ g}^{-1}\right)\end{array}$ & $\begin{array}{c}\text { Onset } \\
\left({ }^{\circ} \mathbf{C}\right)\end{array}$ & $\begin{array}{c}\text { Maximum } \\
\left({ }^{\circ} \mathbf{C}\right)\end{array}$ & $\begin{array}{c}\text { Endset } \\
\left({ }^{\circ} \mathbf{C}\right)\end{array}$ & $\begin{array}{c}\Delta \mathbf{H} \\
\left(\mathbf{J ~ g ~}^{-1}\right)\end{array}$ \\
\hline $\mathbf{3}$ & 33.1 & 100.6 & 204.7 & -163.7 & 520.0 & 582.0 & 580.0 & -10.7 \\
$\mathbf{6}$ & 31.0 & 94.6 & 230.4 & -220.2 & 504.4 & 538.5 & 582.3 & -61.6 \\
$\mathbf{1 2}$ & 48.9 & 98.2 & 162.3 & -191.0 & 309.7 & 521.5 & 313.9 & -1.7 \\
$\mathbf{1 5}$ & 40.4 & 102.2 & 233.3 & -305.0 & 245.6 & 296.4 & 365.9 & -43.0 \\
\hline
\end{tabular}

lated to removal of free water from the samples and the second peak is linked to the removal of water formed by the condensation of $\mathrm{OH}$ groups. The enthalpy changes were calculated from the areas of the observed peaks. The high enthalpy change $(\Delta \mathrm{H})$ of the first peak than that of the second peak indicated the presence of higher amount of free water than bound water in the samples.

The elemental composition of the samples displayed in Table 2 were determined by CHNS elemental analyzer. The samples contained $\mathrm{N}$ and $\mathrm{C}$ elements besides $\mathrm{H}$. The samples contained 1.19 to $2.02 \%$. N which might be present as $\mathrm{NO}_{3}^{-}$ions. The presence of carbon $(0.39-1.51 \%)$ in the samples may be due to the $\mathrm{CO}_{2}$ adsorption of the samples from the air.

Table 2. C, $\mathrm{H}, \mathrm{N}$ element $\%$ of zinc borates obtained at different time of heating.

\begin{tabular}{cccc}
\hline \multirow{3}{*}{ Time (h) } & \multicolumn{3}{c}{ Average (wt \%) } \\
\cline { 2 - 4 } & $\mathbf{C}$ & $\mathbf{H}$ & $\mathbf{N}$ \\
\hline $\mathbf{3}$ & $0.43 \pm 0.10$ & $1.99 \pm 0.04$ & $1.19 \pm 0.01$ \\
$\mathbf{6}$ & $0.44 \pm 0.02$ & $2.15 \pm 0.09$ & $2.13 \pm 0.01$ \\
$\mathbf{1 2}$ & $0.39 \pm 0.10$ & $1.99 \pm 0.06$ & $1.77 \pm 0.01$ \\
$\mathbf{1 5}$ & $1.51 \pm 0.05$ & $2.30 \pm 0.04$ & $2.02 \pm 0.01$ \\
\hline
\end{tabular}

$\mathrm{ZnO} \%$ and $\mathrm{B}_{2} \mathrm{O}_{3} \%, \mathrm{CO}_{3}{ }^{2-}$ and $\mathrm{NO}_{3}{ }^{-}$, contents of the samples are shown in Table $3 . \mathrm{B}_{2} \mathrm{O}_{3} / \mathrm{ZnO}$ molar ratio of samples for different mixing periods is changing between 0.683 and 0.755 as seen in the Table 3 . This results the empirical formula of the zinc borate obtained as $2 \mathrm{ZnO} \cdot 3 \mathrm{~B}_{2} \mathrm{O}_{3} \cdot \mathrm{xH}_{2} \mathrm{O}$.

Water content of the samples were determined by three different methods. The first method is thermogravimetric analysis. The total mass loss at $600^{\circ} \mathrm{C}$ corresponds to elimination of water from the samples. The second method is CHNS analysis. It can be assumed that the $\mathrm{H}$ in the samples can only be present as $\mathrm{H}_{2} \mathrm{O}$ or $\mathrm{OH}$. The third method is related to the material balance of chemical analysis. The difference between 100 and the summation of $\mathrm{B}_{2} \mathrm{O}_{3} \%, \mathrm{ZnO} \%$, $\mathrm{CO}_{3}{ }^{2-} \%$ and $\mathrm{NO}_{3}-\%$ gives the water content by material balance. Mass losses of the samples are changing from $9.48 \%$ to $17.07 \%$ by to TG analysis, $17.91-20.7$ $\%$ by CHNS elemental and $9.36 \%$ to $16.50 \%$ by material balance.

$2 \mathrm{ZnO} \cdot 3 \mathrm{~B}_{2} \mathrm{O}_{3} \cdot 3 \mathrm{H}_{2} \mathrm{O}$ and $\mathrm{ZnO} \cdot \mathrm{B}_{2} \mathrm{O}_{3} \cdot 2 \mathrm{H}_{2} \mathrm{O}$ contain $12.69 \%$ and $19.25 \% \mathrm{H}_{2} \mathrm{O}$, respectively [22], [23]. The water content of $2 \mathrm{ZnO} \cdot 3 \mathrm{~B}_{2} \mathrm{O}_{3} \cdot 3 \mathrm{H}_{2} \mathrm{O}$ is eliminated above $340^{\circ} \mathrm{C}$ [22], the samples prepared in the present study can not be $2 \mathrm{ZnO} \cdot 3 \mathrm{~B}_{2} \mathrm{O}_{3} \cdot 3 \mathrm{H}_{2} \mathrm{O}$ since their maximum dehydration temperature is around $100^{\circ} \mathrm{C}$ as DSC analysis indicated.

Particle size distributions of samples are found as bidisperse as shown in Figure 5 . There is a small peak being maximum around $600 \mathrm{~nm}$, and a big peak around $20 \mu \mathrm{m}$. The mean particle diameter of zinc borate particles were increased with heating time from $16.78,18.93,18.22$ and $22.36 \mu \mathrm{m}$ for $3,6,12$ and 15 hours heating time, respectively. These large particles were thought to be formed by the agglomeration of the nanoparticles formed by homogeneous precipitation.

SEM images of the sample heated for 3 hours are ex-

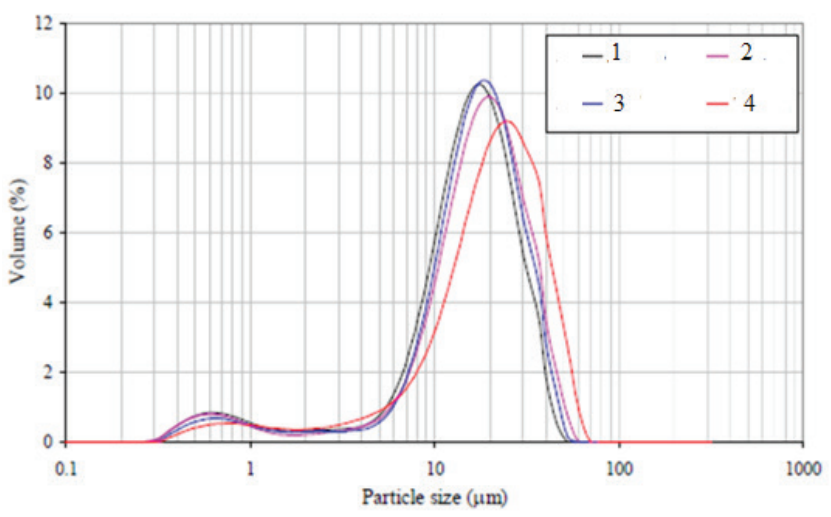

Figure 5. Particle size distribution of samples heated for 3 (Plot 1), 6 (Plot 2), 12 (Plot 3) and 15 (Plot 4) hours at $45^{\circ} \mathrm{C}$ during their preparation.

Table 3. $\mathrm{ZnO}, \mathrm{B}_{2} \mathrm{O}_{3}, \mathrm{CO}_{3}{ }^{2-}$ and $\mathrm{NO}_{3}{ }^{-}$weight $\%$ and $\mathrm{B}_{2} \mathrm{O}_{3} / \mathrm{ZnO}$ molar ratio and $\mathrm{H}_{2} \mathrm{O}$ weight $\%$ of zinc borates.

\begin{tabular}{|c|c|c|c|c|c|c|c|c|}
\hline \multirow{2}{*}{ Time (h) } & \multicolumn{4}{|c|}{ Weight (\%) } & \multirow{2}{*}{$\begin{array}{l}\mathrm{B}_{2} \mathrm{O}_{3} / \mathrm{ZnO} \\
\text { mol ratio }\end{array}$} & \multicolumn{3}{|c|}{$\mathrm{H}_{2} \mathrm{O}(\%)$} \\
\hline & $\mathrm{ZnO}$ & $\mathrm{B}_{2} \mathrm{O}_{3}$ & $\mathrm{CO}_{3}{ }^{2-}$ & $\mathrm{NO}_{3}{ }^{-}$ & & TG & CHNS & Chem. \\
\hline 3 & 44.81 & 31.27 & 2.15 & 5.27 & 0.683 & 9.48 & 17.91 & 16.50 \\
\hline 6 & 42.28 & 30.94 & 2.20 & 9.43 & 0.736 & 14.76 & 19.35 & 15.15 \\
\hline 12 & 43.78 & 30.95 & 1.95 & 7.84 & 0.734 & 17.07 & 17.91 & 15.48 \\
\hline 15 & 42.36 & 31.78 & 7.55 & 8.95 & 0.755 & 13.89 & 20.70 & 9.36 \\
\hline
\end{tabular}



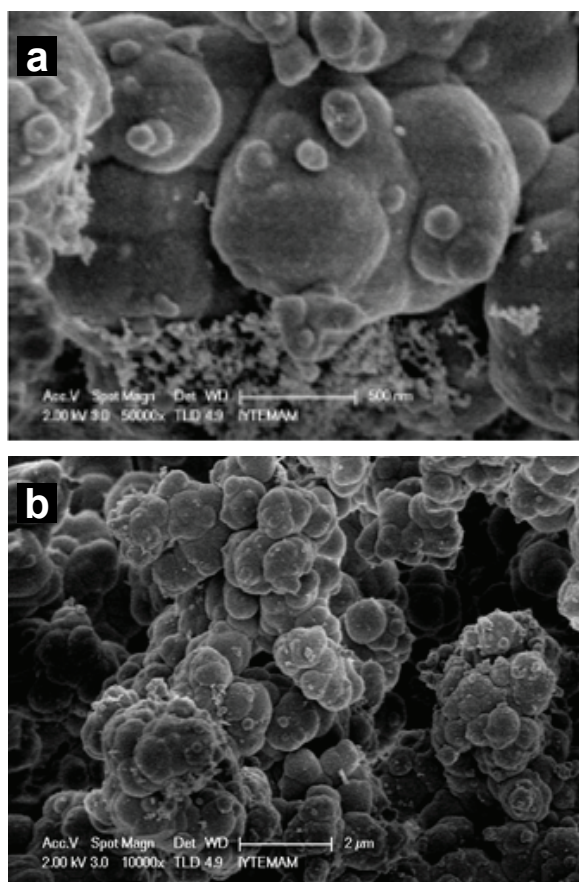

Figure 6. SEM micrographs of the sample heated for 3 hours at $45^{\circ} \mathrm{C}$ during its preparation. At a. $50000 \mathrm{x}$, b. $10000 \mathrm{x}$ magnification. The scale is $500 \mathrm{~nm}$ and $2 \mu \mathrm{m}$ for $\mathrm{a}$ and $\mathrm{b}$, respectively.

hibited in Figure 6. Spherical agglomerates are with $100-500 \mathrm{~nm}$ size are observed in Figure 6a. The agglomerated particles were also sticked together to form larger particles as seen in Figure $6 \mathrm{~b}$. Since the particle size analysis indicated the presence of particles around $20 \mu \mathrm{m}$, these particles were also further agglomerated. It was thought that these agglomerates formed by continuous mixing of the precipitation medium at high rate, $600 \mathrm{rpm}$ for long period. The decrease in stirring rate could solve the agglomeration problem. This problem of agglomeration were also observed by other investigators [7-9].

\subsection{Characterization of Lubricants and Wear Sur- faces}

\subsubsection{Optical microscopy of lubricants}

The inorganic additives were used simultaneously with dispersants in lubricants. The surfactant, sorbitan monostearate (Span 60) was employed as dispersant in the present study. Figure 7 indicates the optical microphotographs of the spindle oil (L1), spindle I oil with dispersant (L2) and spindle oil with dispersant and zinc borate heated for 15 hours (L5). The microphotograph of the spindle oil (Figure $7 a$ ) has only an air bubble, whereas, the microphotographs of the oil with additives has the polydispersed particles. The spindle oil with Span 60 has rod-like shape particles with 5.55 $\mu \mathrm{m}$ average length (Figure $7 \mathrm{~b}$ ). When the zinc borate mixed for 15 hours is added into spindle oil, average diameter of the particles is $3.06 \mu \mathrm{m}$ (Figure 7c). Span 60 covered the zinc borate particles and therefore rod like Span 60 particles are not present. The particle size of the samples differs than the values measured by
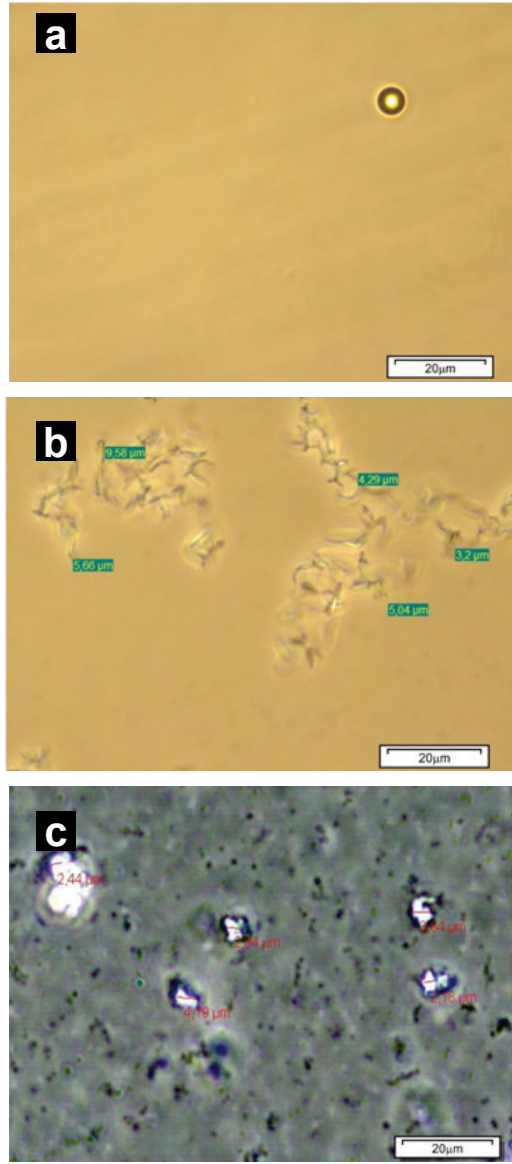

Figure 7. Optical micrographs of a. Spindle oil (L1), b. Spindle oil and dispersant (L2), c. Spindle oil with dispersant and zinc borate heated for 15 hours.

particle size distribution analysis since the zinc borate particles are well dispersed in mineral oil. Besides, the homogenization process during lubricant preparation disperses the agglomerated zinc borate particles.

\subsubsection{Tribological properties of the lubricants}

Colloidal boron compounds are more effective extreme pressure and antiwear additives compared to sulfur and phosphorous containing additives which are considered causing damage to both engine and environment [24-27]. Zinc borate particles are added to spindle oil and four ball tests were applied to determine the tribological properties in the present study. Results of the four ball tests of the lubricants are reported in Table 4 for both the present study and previous studies.

At $75^{\circ} \mathrm{C}$, the four ball test temperature, Span 60 dispersed in spindle oil is in liquid form since it melts at $50^{\circ} \mathrm{C}[18]$. It has strong effect on reducing friction coefficient and wear scar diameter in four ball tests since it can be adsorbed on the surfaces of the balls with its polar ester groups. When Span 60 and zinc borate are added simultaneously to spindle oil, Span 60 ensures the even dispersion of zinc borate particles. On the other hand, Span 60 addition to spindle oil lowered the coefficient of friction from 0.1 to 0.07 . The friction 
Table 4. Tribological properties of lubricants.

\begin{tabular}{|c|c|c|c|c|}
\hline Code & Lubricant & $\begin{array}{l}\text { Friction } \\
\text { coefficient }\end{array}$ & $\begin{array}{c}\text { Wear scar } \\
\text { diameter }(\mathrm{mm})\end{array}$ & Reference \\
\hline L1 & Spindle oil & 0.10 & 1.40 & Present study \\
\hline L2 & Spindle oil with Span 60 & 0.07 & 0.66 & Present study \\
\hline L3 & Spindle oil with Span 60 and zinc borate 6 hour & 0.09 & 0.56 & Present study \\
\hline L4 & Spindle oil with Span 60 and zinc borate 12 hour & 0.07 & 0.53 & Present study \\
\hline L5 & Spindle oil with Span 60 and zinc borate 15 hour & 0.08 & 0.53 & Present study \\
\hline - & $\begin{array}{l}\text { Nano zinc borate and Span 60in mineral oil by } \\
\text { inverse emulsion }\end{array}$ & 0.09 & 0.60 & [3] \\
\hline- & Nano zinc borate and Span 60 in mineral oil & 0.08 & 0.69 & [14] \\
\hline
\end{tabular}

coefficient of spindle oil with Span 60 and zinc borate prepared by mixing 6,12 and 9 hours had friction coefficients of $0.09,0.07$ and 0.08 respectively (Table 4). The wear scar diameter was reduced from $1.4 \mathrm{~mm}$ to $0.66 \mathrm{~mm}$ by addition of the sufactant Span 60 . It was $0.56 \mathrm{~mm}, 0.53 \mathrm{~mm}$ and $0.53 \mathrm{~mm}$ for the lubricant with both surfactant and zinc borates prepared in 6, 12 and 15 hours respectively as seen in Table 4 . Thus wear scar diameter of the lubricant with zinc borate heated for 12 hours was smaller than $61.8 \%$ than the spindle oil (L1). The zinc borates lowered the wear scar diameter compared to that of the spindle oil having only surfactant (L2) (Table 4). Lubricant with Span 60 and nano zinc borate prepared by heating for 12 hours had minimum coefficient of friction and wear scar diameter among the present and previous studies $[3,14]$ as presented in Table 4. The decrease in the wear of the surfaces with lubricants with zinc borate particles is due to filling of the cavities created on the worn surface by them. Therefore, the smoother surfaces result in a decrease in shearing stress and tribological properties.

\subsubsection{Surface topography and composition of the worn balls}

The surface topography of unworn and worn surfaces of the test are shown in Figure 8 and their average surface roughness values measured by AFM are tabulated in Table 5. The images showed that no new phase was obtained on the rubbed surfaces of the test balls. The agglomeration of particles on the pit in Figure 8a might be the deposition film on the friction contacting area. Figure $8 \mathrm{~b}$ exhibits much smoother surface. The surface roughness was also decreased from $35.63 \mathrm{~nm}$ to $27.60 \mathrm{~nm}$ by the addition of zinc borate to spindle oil having Span 60.

The fixed balls lubricated with spindle oil (L1), spindle oil and sorbitan monostearate (L2), the lubricant containing sorbitan monostearate and zinc borate (L5) were cut with a microcutter for closer examination of worn surfaces by SEM. The scars and pits observed by AFM on the surfaces are also visible in SEM micrographs of worn surfaces in Figure 9.

The elemental composition of unworn, worn and de- formed surface of the fixed ball lubricated with the oil with Span 60 and zinc borate particles was determined by EDX (Figure 8c). The white, red and green frames in Figure 9c represent areas of pristine, worn and deformed surfaces. The EDX analysis results of these surfaces are listed in Table 6. The oxygen content is higher for the deformed and worn surfaces than that of pristine surface due to oxidation by cooling water used during cutting process. Boron content was also higher for the worn surface. While in previous stud-
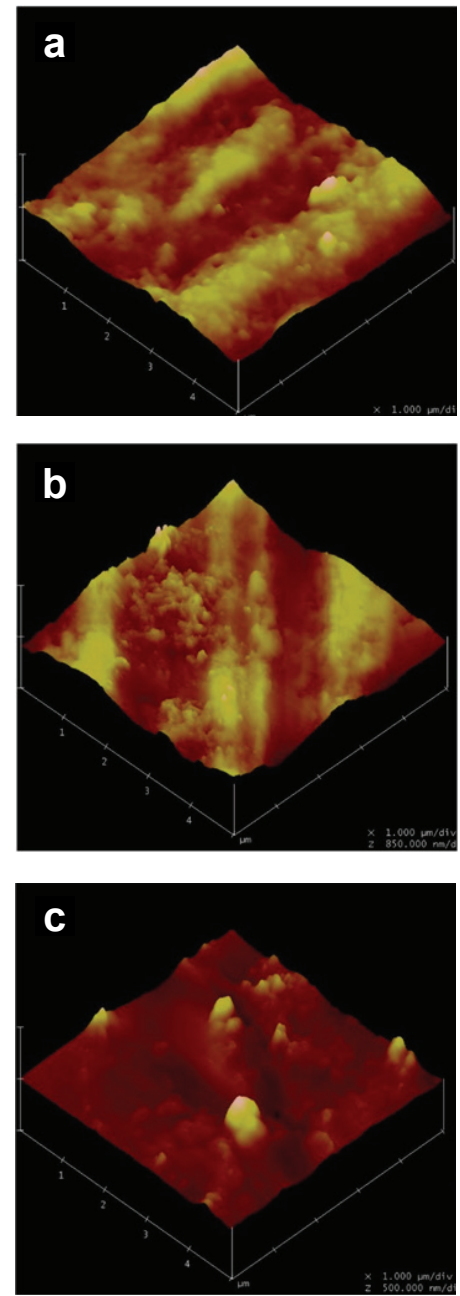

Figure 8. Three dimensional AFM view of $5 \mu \mathrm{m} \times 5 \mu \mathrm{m}$ are of worn surfaces of balls after four ball tests. Surfaces of ball tested with a. Spindle oil, b. Spindle oil with Span 60 c. Spindle oil with Span 60 and zinc borate heated for 15 hours. 
Table 5. Surface rougness and hardness of values unworn and worn surfaces of test balls after four ball tests.

\begin{tabular}{lcc}
\hline \multicolumn{1}{c}{ Ball Surface } & $\begin{array}{c}\text { Surface Roughness } \\
\mathbf{R}_{\mathbf{a}}(\mathbf{n m})\end{array}$ & $\begin{array}{c}\text { Surface Hardness } \\
\text { Vickers }\end{array}$ \\
\hline Unworn & 35.37 & 709 \\
Worn with Spindle oil (L1) & 27.10 & 677 \\
Worn with Spindle oil with Span 60 (L2) & 35.63 & 688 \\
Worn with Spindle oil with Span 60 and zinc borate (L5) & 27.60 & 618 \\
\hline
\end{tabular}

ies either only B element [25] or Zn element [16] was found on the worn surface, both elements existed simultaneously in the present study. This indicated that zinc borate particles were embedded on the surface.
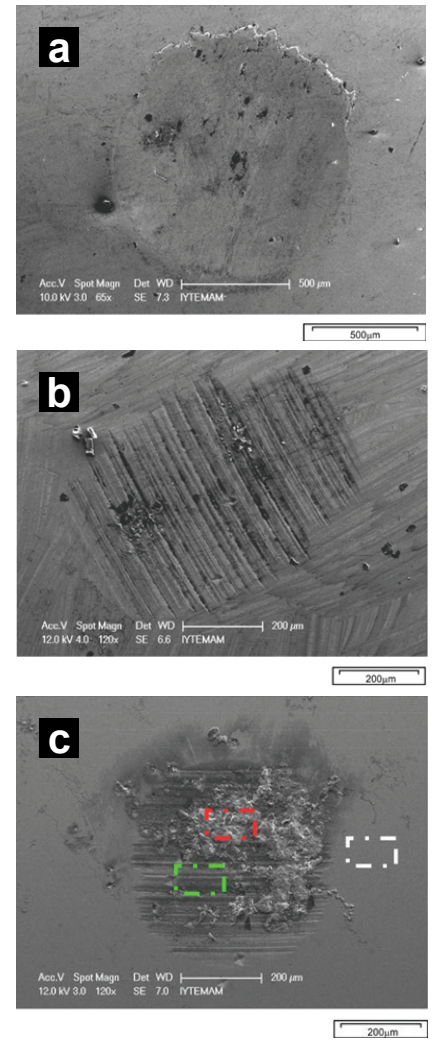

Figure 9. SEM micrographs of warn surfaces of balls after four ball tests with a. Spindle oil (L1) b. Spindle oil with Span 60 (L2), c. Spindle oil with Span 60 and zinc borate heated for 15 hours (L5) (white frame: Pristine surface, red frame: Worn surface, green frame. Deformed surface.

\subsubsection{Surface hardness}

The hardness of pristine and worn surfaces of four ball test balls was measured by indentation test and results are shown in Table 5. The average Vickers hardness value of the pristine ball surface was found as $709 \mathrm{HV}$ (equivalent to $61 \mathrm{HRC}$ ). This value is consistent with literature value of 52100 steel which is 59$61 \mathrm{HRC}$. The average Vickers hardness values of the balls lubricated with spindle oil (L1), spindle oil with surfactant (L2) and the lubricant including zinc borate (L5) were measured as 677, 688 and $618 \mathrm{HV}$, respectively. The hardness of the worn surface with oil with Span 60 is higher than that of the worn surface with pure oil (L1). This can be explained by the migration of polar groups to the metal surface and formation of physical bonds with surfaces. However, the addition of zinc borate particles to spindle oil (L5) considerably decreases hardness of worn surface. A soft thin layer which candeform easily could be the cause of this behavior. Therefore the pressure is decreased due to the decrease of the contact area between the rubbing surfaces and the wear scar diameter is lowered, as well $[15,28]$.

Table 6. Elemental composition of unworn, worn and deformed surfaces of the fixed ball after four ball test with lubricant with Span 60 and zinc borate.

\begin{tabular}{lccc}
\hline \multirow{1}{*}{ Element } & \multicolumn{3}{c}{ Mass (\%) } \\
\cline { 2 - 4 } & $\begin{array}{c}\text { Pristine } \\
\text { Surface }\end{array}$ & $\begin{array}{c}\text { Worn } \\
\text { Surface }\end{array}$ & $\begin{array}{c}\text { Deformed } \\
\text { Surface }\end{array}$ \\
\hline Carbon & 4.8 & 18.5 & 38.4 \\
Oxygen & 1.7 & 8.4 & 13.5 \\
Silicon & 80.3 & 56.2 & 21.0 \\
Chromium & 0.8 & 0.4 & 0.8 \\
Manganese & 1.4 & 1.3 & 0.6 \\
Sulfur & 2.0 & 0.7 & 0.6 \\
Phosphorous & 0.4 & 0.2 & 0.4 \\
Nickel & 0.6 & 0.1 & 0.2 \\
Calcium & 2.6 & 1.1 & 0.9 \\
Boron & 0.2 & 0.2 & 0.6 \\
Zinc & 5.4 & 10.8 & 21.4 \\
\hline
\end{tabular}

\section{Conclusions}

In this study, zinc borates were obtained from zinc nitrate and borax solutions. Dissolution of zinc borate with ammonia and reprecipitation by removing ammonia resulted in formation of nanoparticles of zinc borate. The FTIR spectra of the samples confirm the presence of borate groups. XRD of the samples appear as if they belong to amorphous substances. Spherical agglomerated particles were formed due to mixing of the precipitation medium at high rate for long periods. The mean particle diameter of zinc borate particles dispersed in water were measured as 16.78 $\mu \mathrm{m}, 18.93 \mu \mathrm{m}, 18.22 \mu \mathrm{m}$ and $22.36 \mu \mathrm{m}$ for $3,6,12$ and 15 hours heating at $45^{\circ} \mathrm{C}$ during preparation of zinc borates respectively. 
The zinc borate particles were well dispersed in spindle oil with average diameter of $3.06 \mu \mathrm{m}$. In the lubricant large sized particles such as $22.36 \mu \mathrm{m}$ was not detected which confirmed the homogenization process during lubricant preparation well dispersed the agglomerated zinc borate particles. The zinc borate particles also points their potential use as tribological additives. The wear scar diameter was reduced by $61.8 \%$ for lubricant containing zinc borate and Span 60 as compared to the spindle oil. The boron and zinc contents of the worn surfaces lubricated with oil with zinc borate were higher than that of the unworn surfaces. This may be caused by the presence of embedded zinc borate additive on the worn surface. The hardness of the worn surface lubricated with spindle oil containing surfactant was highest one compared to the surfaces lubricated with only oil and oil having both zinc borate and surfactant.

\section{Acknowledgement}

The authors thank to OPET Mineral Oil Factory for the measurement of tribological properties of the lubricants. Turkish Scientific and Technological Research Council is acknowledged for supporting this study with project number 105M358.

\section{References}

[1] Gao, P. Q., Song, W. H, \& Wang X. (2013). Preparation and characterization of nano zinc borate/epoxide resin composite. Key Engineering Materials, 567, 87-90.

[2] Mergen, A., Ipek, Y., Bolek, H., \& Oksuz, M. (2012). Production of nano zinc borate $(4 \mathrm{ZnO} \cdot \mathrm{B} 2 \mathrm{O} 3 \cdot \mathrm{H} 2 \mathrm{O})$ and its effect on PVC. Journal of Europan Ceramic Society, 32, 2001-2005.

[3] Savrık, S. A., Balköse, D., \& Ülkü, S. (2011). Synthesis of zinc borate by inverse emulsion technique for lubrication. Journal of Thermal Analysis and Calorimetry, 104(201), 605-612.

[4] Li, S., Long, B., Wang, Z., Tian, Y., Zheng, Y., \& Zhang, Q. (2010). Synthesis of hydrophobic zinc borate nanoflakes and its effect on flame retardant properties of polyethylene. Journal of Solid State Chemisty,183, 957-962.

[5] Saffari, H. R. M., Soltani, R., Alaei, M., \& Soleymani, M. (2018). Tribological properties of water-based drilling fluids with borate nanoparticles as lubricant additives, Journal of Petroleum Science and Engineering, $171,253-259$

[6] Ipek, Y. (2020). Effect of surfactant types on particle size and morphology of flame retardant zinc borate powder, Turkish Journal of Chemistry, 44, 214-223.

[7] Baltacı B. (2010). Synthesis and Characterizatıon of Nano Zinc Borate and Its Usage as A Flame Retardant for Polymers [M. Sc. thesis, Middle East Technical Universitiy]. Council of Higher Education Thesis Center (Thesis Number 286210).

[8] Baltaci, B., Cakal, G. O., Bayram, G., Eroglu, I., Ozkar,
S. (2013). Surfactant modified zinc borate synthesis and its effect on the properties of PET. Powder Technology, 244,38-44.

[9] Cakal, G. O., Baltaci, B., Bayram, G., Ozkar S., \& Eroglu, I. (2020). Synthesis of zinc borate using water soluble additives: Kinetics and product characterization. Journal of Crystal Growth, 533, 125461.

[10] Cui, Y., Liu, X., Tian, Y., Ding, N., \& Wang, Z. (2012). Controllable synthesis of three kinds of zinc borates and flame retardant properties in polyurethane foam. Colloids and Surfaces A: Physicocheical and Engineering Aspects 414, 274-280.

[11] Polat, S., \& Sayan, P. (2020) Box-Behnken experimental design for zinc borate $\mathrm{Zn} 2 \mathrm{~B} 6 \mathrm{O} 11 \cdot 7 \mathrm{H} 2 \mathrm{O}$. Journal of Boron, 5(3), 152-161.

[12] Gao, J., Yin, H., Wang, A., \& Jiang, T. (2013). Preparation of zinc borates with different structures and morphologies and their effect on thermal and oxidative stability of polyvinyl alcohol. Powder Technology, 237, 537-542.

[13] Durrani, H., Sharma, V., Bamboria, D., Shukla, A., Basak, S., \& Ali, W. (2020). Exploration of flame retardant efficacy of cellulosic fabric using in-situ synthesized zinc borate particles, Cellulose, 27, 9061-9073.

[14] Savrik, S. A., Alp, B., Ustun, F., \& Balköse, D. (2018). Nano zinc Borate as a lubricant additive. Journal of Turkish Chemical Society A, 5(1), 45-52.

[15] Zhao, C., Jiao, Y., Chen, Y., \& Ren, G. (2014). The Tri bological Properties of Zinc Borate Ultrafine Powder as a Lubricant Additive in Sunflower Oil. Tribology Transactions, 57, 425-434.

[16] Zhao, C., Chen, Y.K., Jiao, Y., Loya, A., \& Ren, G. G., (2014). The preparation and tribological properties of surface modified zinc borate ultrafine powder as a lubricant additive in liquid paraffin. Tribology International 70, 155-164.

[17] Ting, C., Deng, J. C., Shuo, W. L., \& Gang, F. (2009). Preparation and Characterization of Nano-Zinc Borate by a New Method. Journal of Materials Processing Technology, 209, 4076-4079.

[18] Savrik S. A. (2010). Enhancement of Tribologıcal Properties of Mineral Oil by Addition of Sorbitan Monostearate and Zinc Borate [PhD Thesis, İzmir Institute of Technology). Council of Higher Education Thesis Center (Thesis number 266584).

[19] Gao, Y. H., \& Liu, Z. H. (2009). Synthesis and thermochemistry of two zinc borates, $\mathrm{Zn} 2 \mathrm{~B} 6 \mathrm{O} 11 \cdot 7 \mathrm{H} 2 \mathrm{O}$ and Zn3B10O18-14H2O. Thermochimica Acta, 484, 27-31.

[20] Alp, B., Gonen, M., Savrık, S. A., Balkose, D., \& Ulku, S. (2012). Dehydration, Water Vapor Adsorption and Desorption Behavior of $\mathrm{Zn}[\mathrm{B} 3 \mathrm{O} 3(\mathrm{OH}) 5] \cdot \mathrm{H} 2 \mathrm{O}$ and Zn[B3O4(OH)3]. Drying Technology, 30, 1610-1620.

[21] Moezzi, A., Lee, P., McDonagh, A. M., Michael, B., \& Cortie, M. B. (2020). On the thermal decomposition of zinc hydroxide nitrate, $\mathrm{Zn} 5(\mathrm{OH}) 8(\mathrm{NO} 3) 2 \cdot 2 \mathrm{H} 2 \mathrm{O}$. Jourmal of Solid State Chemisty, 286, 121311. 
[22] Schubert, D. M. (2019). Hydrated zinc borates and their industrial use. Molecules, 24, 2419.

[23] Briggs, M. (2001). Boron oxides, boric acid, and borates. Kirk-Othmer Encyclopedia of Chemical Technology, John Wiley \& Sons, Inc.

[24] Zheng, Y., Tian, Y., Ma, H., Qu, Y., Wang, Z. ., An, D., ... \& Gao, X. (2009). Synthesis and performance study of zinc borate nanowhiskers. Colloids and Surfaces $A$. 339,178-184.

[25] Dong, J. X., \& Hu, Z. S. (1998). A Study of the antiwear and friction-reducing properties of the lubricant additive, nanometer zinc borate. Tribology International, 31, 219-223.

[26] Erdemir, A. (1995). U.S. Patent No. 5,431,830. Washington, DC: U.S. Patent and Trademark Office.

[27] Lingtong, K., Hua, H., Tianyou, W., Dinghai, H., \& Jianjian F. (2011). Synthesis and surface modification of the nanoscale cerium borate as lubricant additive. Journal of Rare Earths, 29, 1095-1099.

[28] Yu, H., Xu, Y., Shi, P., Xu, B., \& Wang, X. (2008). Tribological Properties and Lubricating Mechanisms of $\mathrm{Cu}$ Nanoparticles in Lubricant. Transactions of Nonferrous Metals Society of China, 18, 636-641. 